'Physicists on Wall Street' is one of many essays in this volume, which spans a wide range of topics. These include the German atomicbomb project, attempts to use nuclear weapons to power space craft, the Warsaw ghetto, deciphering early Etruscan writing, interpretations of quantum physics in the novels of Michel Houellebecq, a proof of an important conjecture in algebraic topology, and scientists gambling in Las Vegas. Each essay focuses on one individual or on a few people, often involving Bernstein's own ample and varied personal experience - in these cases, the essays work well. Unfortunately, in many cases, he is not

\title{
Mapping the cerebral globe
}

\section{A detailed sketch by architect Christopher Wren reveals his surprising contribution to neuroscience, explain Martin Kemp and Nathan Flis.}

It would have been better for Christopher Wren's reputation as "that rare and early prodigy of universal science", in the words of his friend the diarist John Evelyn, if he had not subsequently proved to be an architect of genius. The towering presence of his St Paul's cathedral and magnificently varied London churches, erected in the wake of the 1666 fire, overshadow his achievements in a wide range of sciences that include mathematics, astronomy, microscopy, instrument design, natural philosophy, natural history, anatomy and physiology.

During his years at the University of Oxford, UK, the precocious Wren was part of the circle of thinkers, investigators and experimentalists who were to lay the foundations of the Royal Society. They intended that no part of the natural world or the cosmos should escape systematic analysis, with a precision that can broadly be called mathematical. It is obvious how astronomical studies should fit within this description, but less clear how the results of anatomical dissection could match that ideal. Wren's illustrations for Thomas Willis's 1664 book Cerebri Anatome (The Anatomy of the Brain) demonstrate how this could be accomplished (see example, pictured right).

A good sense of how the seventeenthcentury concept of 'curiosity' fitted with the precise sciences is provided by Bishop John Wilkins, who chaired the founding meeting of the Royal Society. Evelyn, that most assiduous chronicler of his contemporaries, described how Wilkins had constructed "transparent apiaries, which he had built like castles and palaces, and so order'd them one involved and has not done enough background research. His definition of leverage in the first essay is wrong and his diatribe about the dangers of hedge funds is naive. Many of the essays are essentially reports about books that the reader could digest on his or her own.

Bernstein's book contains a lot of interesting science, and many entertaining stories about the people responsible. It is a pity that, at times, the barrier to understanding the science within the essays is larger than it should be.

J. Doyne Farmer is a professor at the Santa Fe Institute, Santa Fe, New Mexico 87501, USA. e-mail: jdf@santafe.edu upon another so as to take the honey without destroying the bees".

Wilkins also exhibited a "wide variety of shadows, dyals, perspectives, and many other artificial, mathematical, and magical curiosities". Most of the devices were contrived by Wilkins himself, but others were credited to "that prodigious young scholar Mr Christopher Wren, who presented me with a piece of white marble, which he had stain'd with a lively red very deepe, as beautiful as if it had been natural".

One of Wren's mathematical inventions was a perspective machine, or perspectograph, an ingenious device that allows a draftsman, squinting through a sight, to trace the lineaments of any object or landscape. One result was his drawing

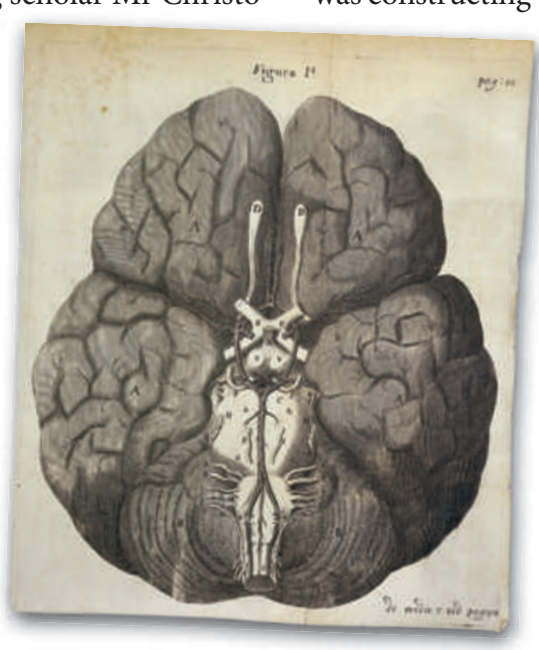

to create the equivalent of a photograph of a dissection - his representations are a succinct synthesis of what Willis and his collaborators had deduced about the structure of the brain over of period of time. To arrive at this point, they exploited the latest techniques of injection to preserve and dye the brain's tissues and vessels. As Willis explained, "let a dyed liquor, and contained in a large squirt or pipe, be injected upwards in the trunk [of an artery] of one side: after once or twice injecting, you shall see the tincture or dyed liquor to descend from the other side by the trunk of the opposite artery".

The resulting illustration (pictured) is, in effect, a complex act of visual pointing, in which key features are elucidated in their plastic and spatial disposition. Of particular concern was the vascular system at the base of the brain, most notably the looped arterial anastomosis, or network of arteries. This had been noticed by earlier writers, but was here given its clearest visual description.

It was the potency of Wren's illustrations, with their precise 'mathematical' character, that led to the anastomosis being designated the Circle of Willis. Willis's renumbering of the cranial nerves still survives and, for good measure, he also coined the term 'neurologie' in his De Anima Brutorum of 1672.

Willis's Cerebri Anatome was dedicated to Archbishop Gilbert Sheldon, for whom Wren was constructing the eponymous Sheldonian entitled 'Prospect of Windsor Castle from the North', engraved by Wenceslaus Hollar for Elias Ashmole's 1672 book Institution, Laws and Ceremonies of the Most Noble Order of the Garter.

Wren's perspectograph was probably used to trace the topography of the brain, its nerves and blood vessels, just as he used a telescope coupled to a micrometer to map the heavens and create the first lunar globe. However, it would be wrong to think that Wren used his instruments and great skill as a draftsman theatre in Oxford. The a ceiling devoid of visible beams, using a system of trusses that Wren devised, perhaps already in collaboration with Robert Hooke, with whom he worked on St Paul's. Hooke, also a distinguished architect, was a notable scientist and creator of Micrographia in 1665, the greatest of all books of microscopic illustration.

Given such conjunctions between architecture and science, it is appropriate that Willis should express unbounded admiration for the way that the "brain, like a castle, divided into many towers or places of defence, is thereby made the stronger and harder to be taken". The cranium and its precious brain were, after all, the greatest designs of nature, the supreme and most prudent architect of all.

Martin Kemp is emeritus professor in history of art at the University of Oxford, Oxford, UK, and author of The Human Animal. Nathan Flis is a doctoral student at the University of Oxford. wide interior is spanned by 